\title{
Examining a servant leadership construct and Its influence on organizational citizenship behavior
}

\author{
Diah Astrini Amir, Claudius Budi Santoso* \\ Faculty of Economics and Business, Universitas Gadjah Mada, Yogyakarta, Indonesia \\ *Corresponding author: bsantoso@ugm.ac.id
}

\begin{abstract}
This study aims to test a servant leadership construct, the Servant Leadership Survey (SLS), in the context of a collective culture. It also examines the effect of each servant leadership (SL) dimension on the organizational citizenship behavior (OCB) of employees. This study uses a validatory factor analysis method to examine the consistency of the SLS construct and, using a purposive sampling approach, involves 295 respondents working in profit and non-profit organizations. The results of this study reveal that only six dimensions of the eightdimensional SL accord with the context of collective culture. The six dimensions are empowerment, standing back, forgiveness, courage, authenticity, and humility. The study also reports that the dimensions of standing back and authenticity have an effect on individual OCB, while the dimensions of empowerment and standing back affect organizational OCB. This study contributes to understanding different cultural contexts (individualistic versus collective) and the requirement to adjust the SL dimensions. These dimensions have different effects on OCB at the individual and organizational levels.
\end{abstract}

Keywords: construct testing, servant leadership, organizational citizenship behavior, Indonesia

\begin{abstract}
Abstrak
Penelitian ini bertujuan untuk menguji konstruk, servant leadership survey (SLS), dalam konteks budaya kolektif. Penelitian ini juga menguji efek dari setiap dimensi servant leadership pada organizational citizenship behavior dari karyawan. Penelitian ini menggunakan metode analisis faktor untuk menguji konsistensi konstruk SLS dan menggunakan metode purposive sampling yang melibatkan 295 responden di organisasi laba dan nirlaba. Hasil penelitian ini mengungkapkan bahwa hanya enam dari delapan dimensi SL yang sesuai dengan konteks budaya kolektif. Keenam dimensi itu adalah pemberdayaan, dukungan, pengampunan, keberanian, keaslian, dan kerendahan hati. Studi ini juga melaporkan bahwa dimensi dukungan dan keaslian memiliki efek pada OCB individu, sedangkan dimensi pemberdayaan dan dukungan mempengaruhi OCB organisasi. Studi ini berkontribusi memberikan pemahaman konteks budaya yang berbeda (individualistik versus kolektif) dan persyaratan untuk menyesuaikan dimensi-dimensi SL. Dimensi ini memiliki efek yang berbeda pada OCB di tingkat individu dan organisasi.
\end{abstract}

Kata kunci: construct testing, servant leadership, organizational citizenship behavior, Indonesia JEL Code: M19 DOI: 10.20885/jsb.vol23.iss1.art4

\section{Introduction}

Servant leadership (SL) is a people-centered concept of leadership style that focuses on serving people's needs. Despite being a new construct in the study of leadership (Van Dierendonck, 2011), SL has become a source of interest to researchers (Barbuto \& Wheeler, 2006; Liden, 2012; Pekerti \& Sendjaya, 2010). SL is considered to be very relevant to the current need of organizations which is to observe the human aspect (regarding individuals) in an organization.

When they were first popularized by Greenleaf (1977), the characteristics of SL were not formally defined and were not based on the results of research. They were therefore limited only to the conceptual stage (Laub, 1999). As a consequence, researchers began to focus on developing SL measurement instruments for the purposes of application. Spears (1995) translated the Greenleaf 
concept into ten SL characteristics. Then, researchers also developed instruments for SL measurement, such as Laub (1999), Dennis and Bocarnea (2005), Barbuto and Wheeler (2006), Liden et al. (2008), as well as Van Dierendonck and Nuijten (2010).

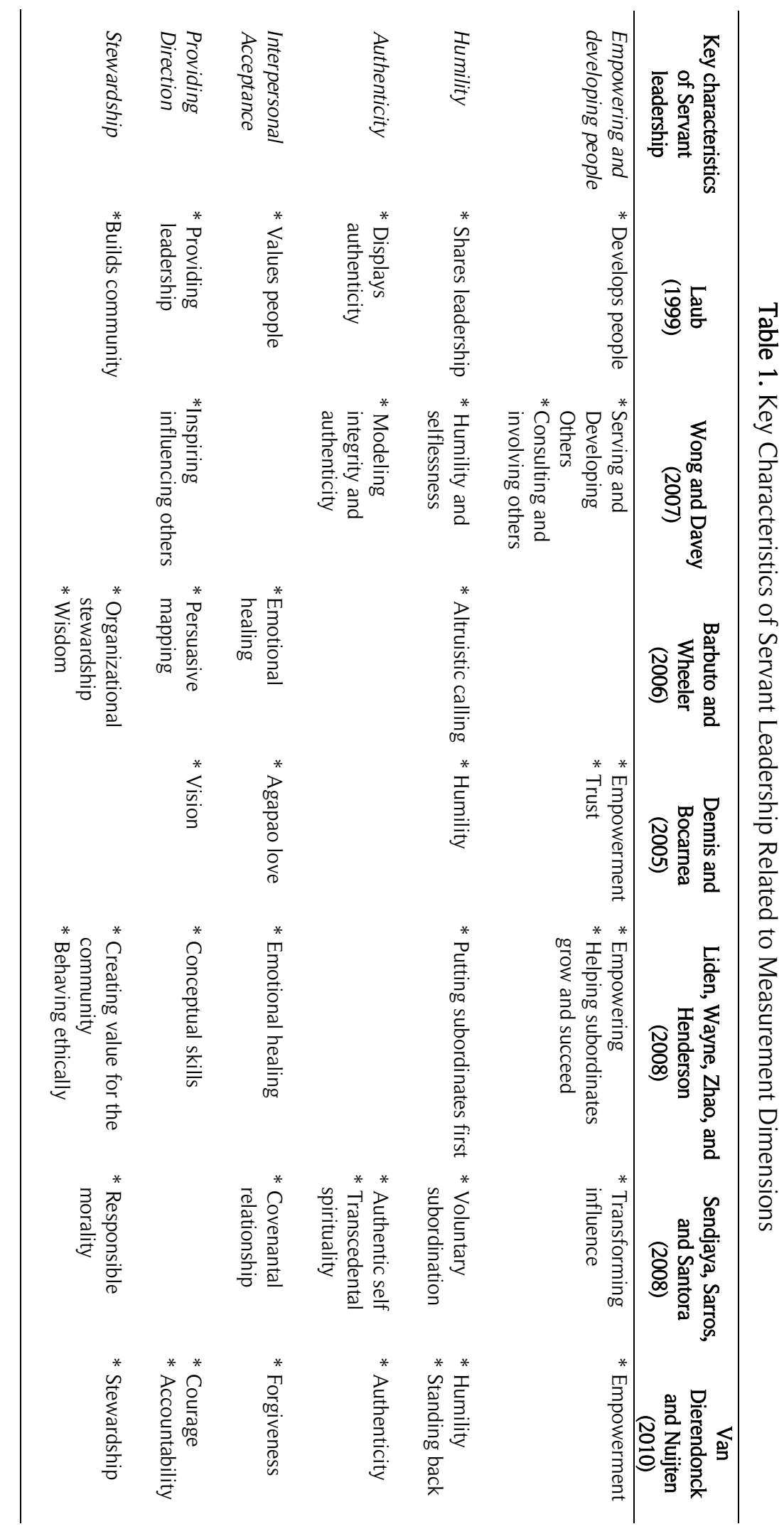


In reference to the studies that developed SL instruments mentioned above (see Table 1), Van Dierendonck (2011) concludes that there are six key SL dimensions, namely: 1) empowerment and developing people; 2) humility; 3) authenticity; 4) interpersonal acceptance; 5) providing direction; and 6) stewardship. These six SL dimensions are more accommodating of the results of the use of SL instruments according to Laub (1999) as well as Van Dierendonck and Nuijten (2010).

Furthermore, Van Dierendonck and Nuijten (2010) developed an SL measurement instrument called the Servant Leadership Survey (SLS). Bobbio et al. (2012) argue that the SLS is effective when used in the context of SL research because it was tested on a factor structure through two qualitative studies and seven quantitative studies (involving nearly 1,200 respondents) in the Netherlands and the UK. Exploratory and confirmatory analysis was used to achieve the stability of the factor structure. Internal consistency testing also showed good results. In addition, this instrument has also passed a series of convergent and discriminant validity tests with other leadership concept measurements such as unidimensional SL, transformational leadership and ethical leadership.

Nonetheless, Van Dierendonck and Nuijten (2010) also revealed that, in order for it to be generalized, the SLS instrument needs to be validated in different countries or different cultural contexts. Bobbio et al. (2012) then responded to this need by validating the SLS instrument in the Italian context. The results of the study reported that thirty (30) SLS items could be replicated in the Italian context which has a cultural structure (i.e. individualistic) that is not very different to the context of the countries where the SLS was developed, namely the Netherlands and the UK. Based on the results of that study, it was deemed necessary to validate the 30 SLS items in the context of a country that has a different cultural structure to those focused on in previous research. In addition, De Waal and Sivro (2012) also recommend further studies to validate the SLS instrument in different cultural contexts. This study responds to this urgent need or challenge by testing the validity of the SLS instrument in an area (country) with a collective culture.

This study takes the view that different cultural groups have different values, thereby causing a different conception of the leadership process (Schwartz, 1994). Mittal and Dorfman (2012) also support the view that there is a difference between the understanding of SL dimensions in countries with individualistic cultures (e.g. European, Nordic cultures) and collective cultures (e.g. in Asia). The dimensions of egalitarianism and empowerment are stronger in Nordic/European culture, but less powerful in Asian culture. On the other hand, the dimensions of empathy and humility are stronger in Asian culture than in European culture. The results of the study conclude that there is a significant relationship between the cultural values of the community and the understanding of SL aspects. Each cultural context will have a unique understanding of the SL dimensions.

Previously, Pekerti and Sendjaya (2010) conducted a study exploring SL in Indonesia as a representation of a collective culture. However, the measurement instruments used by Pekerti and Sendjaya (2010) did not cover the six key characteristics of SL that were the result of the literature review by Van Dierendonck (2011). In addition, the study by Pekerti and Sendjaya (2010) only took samples in two major Indonesian cities and so it has not been able to represent the entire Indonesian nation comprehensively.

Furthermore, this study identifies issues regarding the impact of SL on organizational output variables, i.e. organizational citizenship behavior (OCB) (Dixon, 2013; Mathur \& Negi, 2014; Wu et al., 2013; Newman et al., 2015; Hunter, 2013 ). Based on social learning theory (Bandura, 1971), this study argues that the influence of SL on OCB can be explained as followers' behavior tending to follow the behavior of leaders. SL behavior is the behavior of leaders who is happy serving others. It will motivate followers (individuals) to behave voluntarily to help others. The behavior of the follower or individual is associated with the behavior of OCB (Van Dierendonck, 2011).

Unfortunately, the study of the effect of each SL dimension on OCB, both at the organizational and the individual levels, has not been fully taken into account. This is because the study of the effect of SL on OCB is more viewed as a unidimensional construct. In fact, some empirical studies on SL instruments reveal that SL constructs are multidimensional (Barbuto \& Wheeler, 2006; 
Liden et al., 2008; Sendjaya et al., 2008). Furthermore, the study explains that OCB is divided between the impact of the organization (OCB-O) and individual (OCB-I). However, empirical studies cannot describe the effect of SL on OCB output variables in a comprehensive manner (multidimensional). Therefore, it is important to examine the effect of each SL dimension on OCB on two different levels (OCB-O and OCB-I), in order to provide a comprehensive overview of the effect of SL on OCB.

Based on the above explanation, this study summarizes some of the points of study. Firstly, this study looks at the need for the testing of new SL instruments in a different context (i.e. collective culture) (see Van Dierendonck, 2011; Barbuto \& Wheeler, 2006). Second, this study considers it necessary to examine the six overall dimensions of SL (Van Dierendonck, 2011). Measurement of SL dimensions will use the SLS measurement instrument developed by Van Dierendonck and Nuijten (2010).

\section{Literature Review}

\section{Servant Leadership Dimensions}

Van Dierendonck (2011) describes six key characteristics of SL. These are; 1) empowerment; 2) humility; 3) authenticity; 4) interpersonal acceptance; 5) providing direction; 6) stewardship. These six characteristics of the SL construct are the result of the study of SL instruments by Laub (1999) and Van Dierendonck and Nuijten (2010).

Furthermore, in 2010, Van Dierendonck and Nuijten developed a SL measurement instrument called the Servant Leadership Survey (SLS). The purpose of this study is to produce a valid and reliable measuring instrument in measuring this SL construct. The development of the instrument is based on the literature reviews and opinions of experts in the field of SL. A total of 1,571 respondents were involved from various professional backgrounds in the Dutch and British (UK) contexts. This study combines an exploratory and confirmatory factor analysis approach. The results show that there are eight SL dimensions resulting from a total of 30 question items. The eight SL dimensions include the six key characteristics that are the results of mapping by Van Dierendonck (2011). These eight dimensions are empowerment, standing back, accountability, forgiveness, courage, authenticity, humility, and stewardship. An explanation of each of these dimensions is as follows.

First, Conger (2000) defines empowerment as a motivational concept focusing on the encouragement leaders give to followers (individuals) in the framework of self development. The goal is to foster a proactive and self-confident attitude in the subordinates. These behaviors are shown by encouraging subordinates to make independent decisions, engaging in information sharing, and coaching them to be innovative (Konczak et al., 2000).

The second dimension is standing back and it relates to the ability of a leader to prioritize the interests of the individual first and to provide the support they need. Standing back is also related to the willingness of a leader to become a "player behind the scenes" in achieving things. The leader aims to make subordinates feel more confident about their own abilities. This standing back dimension represents the key SL characteristic, namely humility.

The third dimension is accountability which relates to the ability of leaders to give responsibility to the followers who are under their supervision. Accountability takes place when leaders give responsibility both to individuals and teams (Konczak et al., 2000). The intention is for the followers to know the leaders' expectations from them and bring benefits to their followers on a personal level and to organizations. The dimension of accountability represents a key SL characteristic of providing direction.

The fourth dimension is forgiveness which is forgiving in relation to one's ability to understand and sense the feelings and conditions of others (George, 2000) as well as the ability not to draw attention to the follower's mistakes or to take revenge (McCullough et al., 2000). In other words, interpersonal acceptance is linked to empathy. That is, the psychological ability of a leader to perceive the perspectives of others with a foundation of warm feelings and affection. Interpersonal 
acceptance also relates to the ability of leaders to forgive when a follower commits an offense, gets into an argument, or makes an error. For a servant leader, it is important to create a sense of belief that people feel welcome. Leaders are aware of the gradual learning process, so it takes time for a subordinate to do his or her job perfectly. This forgiving dimension represents the key SL characteristic of interpersonal acceptance.

The fifth dimension is courage which in connection with the bravery of leaders in taking risks. According to Greenleaf (1991), courage is an important characteristic that distinguishes a leader from other leaders. In the organizational context, courage is about improvising conventional working behavior models (Hernandez, 2008). It relates to innovation and creativity that has an impact on the creation of a new solution to a problem. In addition to the accountability dimension, the courage dimension also represents the key SL characteristic of providing direction.

The sixth dimension is authenticity which relates to expressing the true self. In this case, express yourself according to your thoughts and feelings (Harter, 2002). Authenticity is being honest with yourself. Sendjaya et al. (2008) define authenticity as consistency between what they say and their behavior, being honest about limitations, and involvement on moral grounds. This dimension simultaneously represents the key SL characteristic of authenticity.

The seventh dimension is humility which relates to the ability to place one's achievement and talent in a better perspective (Patterson, 2003). Humility in leadership focuses on the courage to admit that a person is not perfect and can make mistakes (Morris et al., 2005). Humility arises from a person's understanding of the strengths and weaknesses they possess. Therefore, a servant leader will acknowledge his or her limitations and therefore actively seek the contributions of others in overcoming such limitations. In addition to the standing back dimension, the dimension of humility represents the key SL characteristic of humility.

The eighth dimension is stewardship which is the willingness to be responsible for a larger institution. Leaders should not only act as caretakers, but also act as role models (Hernandez, 2008). By being a role model, leaders can stimulate others to act in the common interest. Stewardship is closely tied to social responsibility, loyalty, and teamwork. Peterson and Seligman (2004) argue that the constructive desire to serve illustrates the sense of the leaders' obligations to the common good that includes themselves but not in their own personal interests. This dimension of stewardship, at the same time, also represents the key SL characteristic of stewardship.

Based on this description, this study will use the SLS measurement instrument developed by Van Dierendonck and Nuijten (2010) which has passed a series of factor analysis tests using exploratory and confirmatory approaches. Statistically speaking, it is believed that the instrument is very powerful. More specifically, this study will examine the consistency of its eight dimensional SL construct in a different cultural context (i.e. a collective culture) from the ones in the empirical studies above which have focused on indiviualistic cultural contexts.

\section{The effect of Servant Leadership Dimensions on Organizational Citizenship Behavior at the Individual Level}

Williams (2012) mentions that SL tends to be "behind the scenes" with regard to the achievement of the leader's subordinates. In fact, when servant leaders deserve recognition for an achievement, they will remain humble. They show authentic values based on those that they understand in the situation they face with their subordinates. The SL components on the serving side (standing back, humility, and authenticity) are more related to a personal approach to the subordinates.

Therefore, it is assumed that the "serving" component affects the individual level of organizational citizenship behavior (OCB-I). This opinion was empirically supported by the research findings of Williams (2012) which showed that the SL's serving side component affected OCB-I. Based on this, this study will further test the effect of each dimension obtained from the test results of the SL (SLS) measurement instruments (Van Dierendonck and Nuijten, 2010) in terms of OCB-I.

This view is based on social learning theory (Bandura, 1971) which posits that a leader who has a strong influence on social matters tends to be a role model for his subordinates in terms of how 
they behave. SL is characterized by a leader's focus in serving followers' needs. If this is referred to the theory of social learning, then a serving leader will affect the behavior of subordinates who also want to serve others (their peers). More specifically at the individual level, this will be directed at colleagues.

H1: The SL dimensions of the "serving" component has a significant positive effect on the OCB-I of subordinates.

The Influence of Servant Leadership Dimensions on Organizational Citizenship Behavior at the Organizational Level

In general, an SL is known by his or her role as someone who serves the needs of subordinates. However, there are also "leadership roles" that have often been ignored in previous empirical studies (Williams, 2012). Van Dierendonck and Nuijten (2010) in developing the SLS measurement instrument have considered this. In this case, in addition to SL components from the "serving side", there is also the SL component of leadership. The components of this "leadership side" are represented by the SL dimensions: 1) empowerment; 2) accountability; 3) stewardship); and 4) courage.

Empowerment relates to leaders who are aware of the intrinsic potential of each of their subordinates. The ability of leaders to identify the potential of each of their subordinates can be expressed in the form of delegation of tasks or roles to their subordinates in carrying out their duties (Williams, 2012). In addition, servant leaders also have the desire to serve the larger organizations which means they are often faced with the need for courage in making risky decisions (Williams, 2012). Therefore, the characteristics of the servant leaders are suspected to have an effect at the organizational level.

According to social learning theory (Bandura, 1971), leaders who apply the four dimensions of SL will be followed by their subordinates, thus impacting the OCB-O of those followers. In addition there is also Williams (2012) who reveal that the behavior of the servant leader will have an impact at the organizational level. Referring to that discussion, this study will further examine the effect of each dimension on the measurement of the SLS (Van Dierendonck \& Nuijten, 2010) measurement instrument against the OCB-O.

H2: The SL dimensions of the "leadership" component has a significant positive effect on the OCB$O$ of subordinates.

\section{Methods}

\section{Procedures and Samples}

This study uses a statistically quantitative approach. The method of data collection is the use of an online questionnaire, so the data were collected by distributing these questionnaires through a virtual network on the internet to the respondents who then filled them in themselves (Cooper and Schindler, 2014). The advantage of using this method is that it is effective and it can minimize the influence of the interviewer's bias (Neuman, 2014).

The determination of the size of the samples refers to the rule of thumb that posits that a sample that is greater than 30 and less than 500 respondents can be used for various types of research (Sekaran and Bougie, 2009). Hair et al. (2014) also said that a suggested rule of thumb for determining the sample size is a 15: 1 ratio for the number of respondents to the number of research variables. A total of 311 questionnaires were collected but only 295 questionnaires have been processed. Respondents work in for-profit and non-profit organizations. The locations of the respondents' organizations are on Indonesia's larger islands, namely Sumatra, Java, Kalimantan, Sulawesi, and Papua.

This research uses non-probability sampling. More specifically, it uses a purposive sampling technique based on the specific criterion of the duration of the respondent's work with the organization which should be at least one year. This is done in order to ensure that respondents are 
well acquainted with their respective leaders. One year is a sufficient period of time for a respondent to be well-established and to be able to assess the leadership and the impact of those behaviors.

\section{Measurement}

Broadly speaking, there are three variables tested in this study, namely SL, OCB-I and OCB-O using a 5-point Likert Scale that ranges from disagree strongly to agree strongly. The SL variables are measured by the SLS instrument previously developed by Van Dierendonck and Nuijten (2010). The SL variables consist of eight dimensions namely 1) empowerment (7 items); 2) standing back (3 items); 3) authenticity (4 items); 4) humility (5 items); 5) accountability (3 items); 6) courage (2 items); 7) stewardship (3 items); and 8) forgivness (3 items).

OCB uses an instrument developed by Lee and Allen (2002). This instrument is designed to test OCB at the individual level (OCB-I) and the organizational level (OCB-O). OCB-I is measured using 8 question items. One of the items is a statement about "setting aside time to help co-workers who are having problems of both a work and non-work nature". Meanwhile, OCB-O is also measured with 8 question items. One such item is a statement about "offering ideas to improve organizational function".

\section{Results and Discussion}

\section{Validity}

The validity test aims to ensure the items used actually represent the latent construct being measured (Hair et al., 2014). This research uses a confirmatory factor analysis (CFA) method. The method is used to test the validity and consistency of the SLS construct in the different cultural context of organizations in the Indonesian cultural environment. In addition, this study examines the validity of the OCB instrument by using the same approach. In determining the validity level, the researcher refers to the value of loading factor greater than 0.5 (Hair et al., 2014). Before conducting validity tests, there is a requirement for the SLO and Bartlett's Test values to be met. In this study, the required SLO value $>0.5$ and the significance value of Bartlett's Test is $<0.05$ (Hair et al., 2014). The validity test using CFA method in this study was conducted in two rounds.

Based on the validity factor analysis (CFA) method, it is reported that from the eightdimensional SL tested, only six dimensions are eligible for validity testing. These six dimensions are reported to be eligible for validity testing: empowerment, standing back, forgiveness, courage, authenticity, and humility. Meanwhile, the another two dimensions of accountability and stewardship are reported to be ineligible for validity testing. The results show that from the eight-dimensional SL version of SLS, only six dimensions correspond to the context of collective culture (Indonesia).

\section{Reliability}

Furthermore, the reliability test aims to test the consistency of the measuring instrument used in the research (Neuman, 2014). The reliability is tested based on the Cronbach Alpha coefficient value, where the reliability of a measuring instrument can be said to be good when the Cronbach Alpha value is reported to approach 1 (one). Sekaran and Bougie (2009) separate Cronbach's Alpha values in 3 categories, namely; 1) the value of 0.8 to 1.0 is considered to indicate good reliability; 2) the value of 0.6 to 0.79 indicates acceptable reliability; 3 ) a value of $<0.6$ indicates bad reliability. The reliability test results show that the score is in the range of 0.699 to 0.924 . These results show that all items that have passed the validity test are also reliable.

\section{Descriptive Results}

Table 2 shows the results of a statistical descriptive test consisting of average values, standard deviations, and correlations between variables in the data obtained. According to these results, this 
study indicates that the average respondent has a high response to each SL dimension item above 3 but except for the forgiveness dimension (2.95). Meanwhile, the OCB-I and OCB-O variables also showed a fairly high response $(r=3.90$ and $r=3.91)$. In addition, Table 2 also shows the correlation value between SL dimensions and each SL dimension with OCB variables. The results show that SL dimensions and SL dimensions with OCB variables are significantly correlated, except the forgiveness dimension with the courage dimension $(r=-0.02 ; p>0.1)$; authentic dimension $(r=0.01 ; p>0.1)$; OCB-I variables $(r=0.01 ; p>0.1)$; and OCB-O variables $(r=0.06 ; p>0.1)$.

\section{Results of Regression Testing of Servant Leadership against OCB-I}

Based on the multiple regression test results (see Table 3), this study reports that only two SL dimensions have a significant effect on the individual level of organizational citizenship behavior (OCB-I). Both of these dimensions are standing back $(\mathrm{SB})(\beta=0.144 ; \mathrm{t}=1.862 ; \mathrm{p} .0 .064<\mathrm{p} .0 .1)$ and authenticity $(\beta=0.126, t=1.837 ; p .0 .067<\mathrm{p} .0 .1)$. Meanwhile, the four other dimensions, namely empowerment (EMP), forgiveness (FRGV), courage (COU), and humility (HUM) are reported to have no significant effect on OCB-I. These results indicate that Hypothesis 1, which states that the SL dimensions of the "serve" side affect the subordinate individuals' OCB-I, is supported partially.

Although the multiple regression test partially reported that there were only two dimensions affecting OCB-I, the value of $F_{\text {count }}$ (5.637) was reported as being higher than the $F_{\text {table }}$ value (1.77) with a level of significance of 0.000 . The results show that the six dimensions of SL simultaneously have an influence on OCB-I. In addition, the adjusted R square value for the model shows that the all six dimensions of SL in explaining OCB-I is 0.086 .

Table 3: Results of Regression Testing of Servant Leadership against OCB-I

\begin{tabular}{lccc}
\hline \multicolumn{1}{c}{ Variable } & $\begin{array}{c}\text { Standardized } \\
\text { Coefficient }(\boldsymbol{\beta})\end{array}$ & Value t & Sig. \\
\hline Empowerment (EMP) & 0.043 & 0.519 & 0.604 \\
Standing Back (SB) & 0.144 & 1.862 & 0.064 \\
Forgiveness (FRGV) & -0.084 & -1.348 & 0.179 \\
Courage (COU) & -0.012 & -0.177 & 0.860 \\
Authenticity (AUT) & 0.126 & 1.837 & 0.067 \\
Humility (HUM) & 0.115 & 1.417 & 0.158 \\
Value of adjusted $R$ square =0.086 & & & \\
F Value = 5.637 & & & \\
Significance Value = 0.000 & & \\
* The dimensions acountability (ACC) and stewardship (STW) did not pass the validity test \\
Source: Processed primary data (2017)
\end{tabular}

\section{Results of Regression Testing of Servant Leadership against OCB-O}

Based on the multiple regression test results in Table 4, this study reports that only two SL dimensions have a significant effect on organizational citizenship behavior (OCB-O). These two dimensions are empowerment (EMP) $(\beta=0.234 ; \mathrm{t}=2.976 ;$ p.0.003 $<$ p.0.01 $)$ and staying back $(\mathrm{SB})(\beta=0.161, \mathrm{t}=$ 2.181 ; p.0.030 < p.0.05). Meanwhile, the study reports that four other dimensions of forgiveness, courage, authenticity, and humility do not significantly affect OCB-O. These results suggest that Hypothesis 2, which states that the SL dimensions of the "leader" side affect the subordinates in OCB$\mathrm{O}$, is supported partially.

Although the multiple regression test partially reported that there were only two dimensions affecting OCB-O, the value of $F_{\text {count }}(10.923)$ was reported higher than the $F_{\text {table }}$ value (1.77) with a level of significance of 0,000 . The results show that the six dimensions of SL simultaneously have an 
influence on OCB-O. In addition, the adjusted R square value for the model that explains the overall effect of the six-dimensional SL against OCB-O is 0.168.

Table 4. Results of Regression of Testing Servant Leadership against OCB-O

\begin{tabular}{lccc}
\hline \multicolumn{1}{c}{ Variable } & $\begin{array}{c}\text { Standardized } \\
\text { Coefficient }(\boldsymbol{\beta})\end{array}$ & Value t & Sig. \\
\hline Empowerment (EMP) & 0.234 & 2.976 & 0.003 \\
Standing Back (SB) & 0.161 & 2.181 & 0.030 \\
Forgiveness (FRGV) & -0.073 & -1.219 & 0.224 \\
Courage (COU) & 0.014 & 0.220 & 0.826 \\
Autheticity (AUT) & 0.020 & 0.308 & 0.758 \\
Humility (HUM) & 0.097 & 1.243 & 0.215 \\
\hline
\end{tabular}

Adjusted $R$ square Value $=0.168$

F Value $=10.923$

Significance Value $=0.000$

*The dimensions acountability (ACC) and stewardship (STW) did not pass the validity test Source: Processed primary data (2017)

\section{Discussion}

In general, this study aims to test the construct of servant leadership, specifically the SLS (Servant Leadership Survey) developed by Van Dierendonck and Nuijten (2010) in the context of a collective culture (Indonesia). Test results show that from eight SL dimensions in the SLS measurement construct, only six dimensions correspond to the context of the collective culture in Indonesia. The six dimensions are: 1) empowerement; 2) standing back; 3) forgiveness; 4) courage; 5) authenticity; and 6) humility. This result is quite different from the findings of Bobbio et al. (2012) which showed that the eight SL dimensions in the SLS instrument correspond to the Italian and Dutch contexts which both represent typically individualistic culture. The contrast between the current research results and those of previous studies shows that there are significant differences in how to understand the concept of servant leadership in individualistic and collective cultures. This argument is supported by the results of the research by Liden (2012), Mittal and Dorfmann (2012) and Pekerti and Sendjaya (2010) which shows that there are differences between the understanding of SL leadership dimensions in the context of different cultures.

Based on the results of the construct testing, six SL dimensions, namely empowerement, standing back, forgiveness, courage, authenticity, and humility, reflect the characteristics of a serving leader. This means that in the Indonesian context, these six dimensions are the determining factor of a person being called a serving leader. In addition, the results of this study also report that the accountability and stewardship dimensions do not accord with the context of Indonesia's collective culture. The accountability dimension, for example, is a new SL dimension out those acknowledged by Van Dierendonck and Nuijten (2010) and it is often neglected by researchers when measuring SL. Indirectly, the results of this study can explain that the dimension of accountability does not correspond to the context of collective culture in Indonesia because there is no consensus about this dimension reflecting a serving leader.

In addition, the desire to serve dimension which is the hallmark of SL is also reportedly incompatible with the context of collective culture like that in Indonesia. The findings are supported by Pekerti and Sendjaya (2010) who use the term "responsible morality" for the desire to serve dimension. Pekerti and Sendjaya (2010) reveal that responsible morality reflects the behavior of the serving leader who controls the process and the result of servant leadership can be justified ethically. Furthermore, the development of this term refers to Resick et al. (2006) who show that, compared to Anglophone counties (individualistic), the southeast Asian (collective) countries show a much lower 
component of ethical leadership. This result indicates that the national leaders in the Anglophone group of countries are more instrumental in raising the awareness of followers with regard to ethical behavior in carrying out organizational processes than leaders of the group of southeast Asian nations. The same thing is also revealed by Robertson et al. (2008) who showed that the practice of guanxi (Tionghoa), which is in harmony with the principles of collectivism, tends to create privilege and favoritism toward the people in the group which ultimately has an impact in terms of unethical behavior.

In addition, this study also aims to test the effect of each SL dimension on organizational citizenship behavior in terms of the individual (OCB-I) and the organization (OCB-O). The regression test results report that, of the six SL dimensions tested, only two dimensions have an effect on the individual's organizational citizenship behavior (OCB-I). These are the dimensions of standing back and authenticity. This result is in line with Williams (2012) whose research showed that SL dimensions with "serving" aspects tend to affect OCB-I. On the other hand, the humility dimension have no effect on OCB-I. The humility dimension which does not have a significant affect on the OCB-I also demonstrates that, although humility is one of the SL dimensions of the "serving" side, it nevertheless has no effect on OCB-I in the context of collective culture like Indonesia's. Therefore, this study concludes that the dimensions of standing back and authenticity have a significant role in OCB-I in the context of organizations in Indonesia.

Meanwhile, the result of regression analysis shows that from six the SL dimensions, it is reported that the empowerement and standing back dimensions significantly affect OCB-O. The empowerement dimension having a significant effect on OCB-O is supported by the study by Williams (2012). The findings of Williams (2012) reveal that the empowerement SL dimension tends to affect OCB-O.

In addition, the standing back dimension demonstrates a significant effect on OCB-O represents a unique finding of this study. While the research of Williams (2012) reports that the standing back dimension is one of the SL dimensions on the "serving" side and has a significant effect on OCB-I but not on OCB-O, the result of this study shows the opposite result. It shows that in the context of Indonesia's collective culture, the behavior of leaders who tend to play their role as "behind-the-scenes actors" will be the determining factor of the extra-role behavior of followers in the organization.

Finally, these findings provide additional empirical evidence regarding the testing of the SLS construct in the context of collective cultural countries, particularly Indonesia. In general, there are six dimensions of SL that correspond to the Indonesian context, namely empowerement, standing back, forgiveness, courage, authenticity, and humility. In addition, two SL dimensions-i.e. standing back and authenticity - are a strong determining factors that affect the organizational citizenship behavior of the individual follower (OCB-I). At the same time, the empowerment and standing back dimensions affect the organizational citizenship behavior at the organizational level (OCB-O).

\section{Conclusions}

On one hand, some empirical studies have stated that the concept of SL is already universally applicable both to individualistic and collective cultures (Pekerti and Sendjaya, 2010; Mittal and Dorfman, 2012). However, on the other hand, cultural differences also influence leadership perceptions. The results of this study reinforce the understanding that, although SL is a universal leadership concept, there are still differences in the determination of SL dimensions because there are differences found in the context of a country's social culture. The eight-dimensions of the SLS instrument developed by Van Dierendonck and Nujten (2010) are suitable for employees in Britain, the Netherlands and Italy, but it is quite different when they are applied in Indonesia which represents a collective culture. The results of this study reveal that six of the dimensions of the SLS instrument, namely empowerment, standing back, forgiveness, courage, authenticity, and humility, accord with the context of the collective culture represented by the Indonesian context. Meanwhile, two of the 
dimensions, namely accountability and stewardship, are not in line with the characteristics of the serving leader.

Furthermore, two SL dimensions, namely standing back and authenticity, affect the organizational citizenship behavior of the individual follower (OCB-I). The behavior of leaders who tend to act as "behind-the-scenes actors" for the success of their subordinates will encourage voluntary behavior on the part of followers to help their co-workers to achieve mutual success. In addition, the "true self" behavior shown by a leader will contribute to prosocial behaviors by subordinates. There are two SL dimensions, namely empowerement and standing back, that affect the organizational citizenship behavior at the organizational level (OCB-O). Leaders who are focused on the development of the followers will encourage voluntary behavior on the part of those followers which impacts the organization, such as maintaining the organization's image.

The findings of this study contribute to the work of both academics and practitioners. On the academic side, this study gives insight into how the application of the SL dimensions through the SLS instrument needs to take into account the context, particularly culture. Additionally, this study provides specific insight into the impact of each SL dimension on OCB at the individual level (OCBI) and at the organization level (OCB-O). This study fills the gap in previous studies which tended to emphasize SL testing against OCB as being unidimensional.

This research has limitations which create useful ideas for the development of further research. First, the variable measurements in this study are based on self-reporting which may trigger common method bias (Podsakoff et al., 2012). Further research could apply the dyadic method, retrieving data from the perspectives of followers and leaders. Second, this study focuses on examining a servant leadership construct, namely the Servant Leadership Survey developed by Van Dierendonck and Nuijten (2010) in the context of individualistic cultures (Dutch and British). Meanwhile, this study has been conducted in a collective cultural context from previous research. The results of this study show that there are different perceptions related to SL dimensions in a country with a different culture.

\section{References}

Bandura. (1971). Social Learning Theory. New York: General Learning Press.

Barbuto, J. E., \& Wheeler, D. W. (2006). Scale Development and Construct Clarification of Servant Leadership. Group \& Organization Management. 31(3), 300-326.

Bobbio, A., Van Dierendonck, D., \& Manganelli, A. M. (2012). Servant Leadership in Italy and Its Relation to Organizational Variables. Leadership. 8 (3), 229-243.

Conger, J. A. (2000). Motivate performance through empowerment. In E. A. Locke (Ed.), The Blackwell handbook of principles of organizational behavior. Oxford: Blackwell Publishing.

Cooper, R. D., \& Schindler, S.P. (2014). Business Research Methods 12th. New York: McGrawHill.

De Waal, A., \& Sivro, M. (2012). The relation between servant leadership, organizational performance, and the high-performance organization framework. Journal of Leadership \& Organizational Studies, 19(2), 173-190.

Dennis, R. S., \& Bocarnea, M. (2005). Development of the Servant Leadership Assessment Instrument. Leadership \& Organization Development Journal. 26(8), 600-615.

Dixon, D. L. (2013). Relationships Among Servant Leadership, Organizational Citizenship Behavior, and School Climate in Alabama High Schools. A Dissertation. The University of Alabama TUSCALOOSA.

George, J. M. (2000). Emotions and leadership: The role of emotional intelligence. Human Relations. $53,1027-1055$. 
Greenleaf, R. K. (1977). Servant Leadership: A Journey into the Nature of Legitimate Power and Greatness. New York: Paulist Press.

Greenleaf, R. K. "The servant as leader (Rev. ed.)." Indianapolis, IN: Robert K. Greenleaf Center (1991).

Hair, F. J., Black, C. W., Babin, J. B., \& Anderson, E. R. (2014). Multivariate Data Analysis. London: Pearson Education Limited.

Harter, S. (2002). Authenticity. In C. R. Snyder \& S. J. Lopez (Eds.). Handbook of positive psychology. New York: Oxford University Press.

Hernandez, M. (2008). Promoting stewardship behavior in organizations: A leadership model. Journal of Business Ethics, 80, 121-128.

Hunter, E. M., Neubert, M. J., Perry, S. J., Witt, L. A., Penney, L. M., \& Weinberger, E. (2013). Servant Leaders Inspire Servant Followers: Antecedents and Outcomes for Employees and The Organization. The Leadership Quarterly. 24(2), 316-331.

Konczak, L. J., Stelly, D. J., \& Trusty, M. L. (2000). Defining and measuring empowering leader behaviors: Development of an upward feedback instrument. Educational and Psychological Measurement. 60, 301-313.

Laub, J. A. (1999). Assessing the Servant Organization. A Dissertation. Florida Atlantic University.

Lee, K., \& Allen, N. J. (2002). Organizational Citizenship Behavior and Workplace Deviance: The Role of Affect and Cognitions. Journal of Applied Psychology. 87, 131-142.

Liden, R. C., Wayne, S. J., Zhao, H., \& Henderson, D. (2008). Servant Leadership: Development of a Multidimensional Measure and Multi-Level Assessment. The Leadership Quarterly. 19(2), 161-177.

Liden, R. C. (2012). Leadership Research in Asia: A Brief Assessment and Suggestions for The Future. Asia Pacific Journal of Management. 29(2), 205-212.

Mathur, G., \& Negi, P. (2014). Servant Leadership and Organizational Citizenship Behaviour Among Employees of Service Sector. American International Journal of Research in Humanities, Arts, and Social Sciences. 191-196.

McCullough, M. E., Hoyt, W. T., \& Rachal, K. C. (2000). What we know (and need to know) about assessing forgiveness constructs. In M. E. McCullough, K. I. Pargament, \& C. E. Thoresen (Eds.), Forgiveness: Theory, research, and practice (pp. 65-88). NewYork: Guilford Press.

Mittal, R., \& Dorfman, P. W. (2012). Servant leadership across cultures. Journal of World Business, 47(4), 555-570.

Morris, J. A., Brotheridge, C. M., \& Urbanski, J. C. (2005). Bringing humility to leadership: Antecedents and consequences of leader humility. Human Relations, 58, 1323-1350.

Neuman, L. W. (2014). Social Research Methods: Qualitative and Quantitative Approaches 7th edition. London: Pearson Education Limited.

Newman, A., Schwarz, G., Cooper, B., \& Sendjaya, S. (2015). How Servant Leadership Influences Organizational Citizenship Behavior: The Roles of LMX, Empowerment, and Proactive Personality. Journal of Business Ethics. 1-14.

Patterson, K. A. (2003). Servant Leadership: A Theoretical Model (Doctoral dissertation, Regent University, ATT 3082719). 
Pekerti, A. A., \& Sendjaya, S. (2010). Exploring Servant Leadership Across Cultures: Comparative Study in Australia and Indonesia.The International Journal of Human Resource Management. 21(5), 754-780.

Peterson, C., \& Seligman, M. E. P. (2004). Character strengths and virtues: A handbook and classification. Oxford, England: Oxford University Press.

Podsakoff, P. M., MacKenzie, S. B., \& Podsakoff, N. P. (2012). Sources of Method Bias in Social science Research and Recommendations on How to Control It. Annual Review of Psychology, 63, 539-569.

Resick, C.J., Hanges, P.J., Dickson, M.W., and Mitchelson, J.K. (2006), 'A Cross-cultural Examination of the Endorsement of Ethical Leadership. Journal of Business Ethics, 63, 345 - 359.

Robertson, C.J., Olson, B.J., Gilley, K.M., and Bao, Y. (2008), 'A Cross-cultural Comparison of Ethical Orientations and Willingness to Sacrifice Ethical Standards: China versus Peru. Journal of Business Ethics, 81, 413-425.

Schwartz, S. H. (1994). Are there universal aspects in the structure and contents of human values?. Journal of social issues, 50(4), 19-45.

Sekaran, U., \& Bougie, R. (2009). Research Method for Business: A Skill Building Approach. Fifth Edition. United Kingdom: John Wiley dan Sons Ltd.

Sendjaya, S., Sarros, J. C., \& Santora, J. C. (2008). Defining and Measuring Servant Leadership Behaviour in Organizations. Journal of Management Studies. 45(2), 402-424.

Spears, L. C. (Ed.). (1995). Reflections on leadership: How Robert K. Greenleaf's theory of servantleadership influenced today's top management thinkers. Wiley.

Van Dierendonck, D. V., \& Nuijten. (2010). The Servant Leadership Survey: Development and Validation of a Multidimensional Measure. Journal Business Psychology. 26, 249-267.

Van Dierendonck, D. (2011). Servant Leadership: A Review and Synthesis. Journal of Management. 37(4), 1228-1261.

Williams, W. A. (2012). The Impact of Servant Leadership on Follower Outcomes: Testing The Mediating Roles of Stewardship Cimate and Trust. A Dissertation. University of Missisippi.

Wu, L. Z., Tse, E. C. Y., Fu, P., Kwan, H. K., \& Liu, J. (2013). The Impact of Servant Leadership on Hotel Employees Servant Behavior. Cornell Hospitality Quarterly, 54(4), 383-395. 